\title{
Globalising the classical foundations of IPE thought*
}

Eric Helleiner**

\section{Introduction}

Contemporary scholars of international political economy (IPE) have increasingly sought to encourage a 'global conversation' that extends beyond debates between the well-known 'American' and 'British' schools of thought. Greater attention is being devoted to the contributions of IPE scholars from elsewhere, particularly beyond Europe and the United States. To date, however, these efforts to 'globalise' IPE have focused largely on current scholarship. Efforts to teach and research the historical foundations of IPE thought in classical political economy in the $18^{\text {th }}, 19^{\text {th }}$ and early $20^{\text {th }}$ centuries

\footnotetext{
* Received on December $10^{\text {th }} 2014$ and approved for publication on June $9^{\text {th }} 2015$. The author is very grateful to the Social Sciences and Humanities Research Council of Canada for its support as well as to Derek Hall, John Hobson, James Morrison, Antulio Rosales, and two anonymous reviewers of this journal for their very helpful comments.

** Faculty of Arts Chair in International Political Economy and Professor in the Department of Political Science, University of Waterloo, Waterloo, Ontario, Canada. Email: ehelleiner@ uwaterloo.ca.
}

CONTEXTO INTERNACIONAL Rio de Janeiro, vol. 37, n 3, september/december 2015, p. 975-1010. 
remain stubbornly centred on European and American thinkers. If a more extensive 'global conversation' is to be fostered, the perspectives of historical thinkers from other regions need to be brought more into the mainstream of the field's intellectual history.

This article explores one way in which IPE scholars can begin to 'globalise' the history of the classical foundations of IPE thought. IPE textbooks usually identify three core traditions of thought in classical political economy on which current IPE scholarship builds: economic liberalism, economic nationalism and Marxism. As a first step towards developing a more global intellectual history of the classical foundations of IPE, this article demonstrates how thinkers beyond Europe and the United States engaged with and contributed to debates associated with those three traditions before 1939. In so doing, it highlights the fact that global conversations about IPE issues already took place in this earlier age. Those discussions frequently involved the export of European and American ideas in the context of unequal power relations. For various reasons, however, those ideas appealed to many thinkers in other regions who adapted and transformed them in important ways that deserve greater recognition. Core concepts associated with those classical schools were also not all derived from European and American thought; some emerged autonomously in other parts of the world, and ideas flowed from other regions to Europe and the United States as well as among themselves.

\section{Towards a more global conversation}

This article builds on the debates generated by Benjamin Cohen's widely read intellectual history of modern IPE (2008) which suggested that the field had been increasingly dominated since its birth in the early 1970s by two schools, one rooted in Britain and the other in the United States. Cohen's analysis has provoked 


\section{Globalising the classical foundations of IPE thought}

widespread discussions of, and reflections on, the state of IPE (e.g. Phillips and Weaver 2011). Although Cohen's goal of fostering a greater understanding between the British and American schools has been widely appreciated, many scholars have criticised the narrow Anglo-American focus of his history as well as the field more generally. They have called for more attention to be devoted to schools of thought in other parts of the world, particularly regions beyond Europe and the United States, in order to ensure that IPE is more of a 'global conversation' (e.g. Blyth 2009; Leander 2009; Cox 2011; Helleiner 2009; Murphy 2009; Phillips 2005).

In a sequel to the 2008 volume, Cohen (2013) acknowledged the importance of this criticism, and set out to address it by detailing the state of current IPE scholarship in other regions of the world. This task has also been taken up by others, including the contributors to a recent special issue of Review of IPE who explored contemporary Chinese IPE scholarship under the theme of 'IPE in China: the global conversation' (Chin, Pearson and Wang 2014). These and other works have highlighted the distinctiveness of IPE thought in different parts of the world, and provided support for Blyth's assertion (2009: 3) that 'where you sit determines what you think about IPE'.

These efforts to encourage a global conversation about IPE are important, but have been limited by the fact that they focus almost entirely on contemporary IPE scholarship. As Cohen and others have noted, modern IPE builds upon on a rich body of classical political economy scholarship in the $18^{\text {th }}, 19^{\text {th }}$ and early $20^{\text {th }}$ centuries that addressed international and global issues of concern to contemporary IPE scholars. Teaching and research about these classical foundations of IPE thought remain, however, focused primarily on historical thinkers in Europe and the United States who are seen to have pioneered the perspectives of economic liberalism, economic nationalism and Marxism. 
For a field that aspires to building a more global conversation, this narrow geographical focus is problematic. One reason has already received attention in the recent writings of John Hobson (2013a, b) who has shown how many of these thinkers were infused with Eurocentric meta-narratives that assumed Europe to be a standard of civilisation for the rest of the world (see also Blaney and Inayatullah 2010). For contemporary IPE scholars seeking to globalise their field, Hobson argues, these aspects of its historical foundations need to be acknowledged, interrogated and transcended.

Much less attention has been devoted to a second reason why the heavy historical focus on European and American classical thought is problematic. That approach overlooks the perspectives on political economy of historical thinkers in other parts of the world. Contemporary IPE scholars outside Europe and the United States cite and draw upon political economy discussions that were active in their regions during the $18^{\text {th }}, 19^{\text {th }}$ and early $20^{\text {th }}$ centuries. But those discussions, and the thinkers associated with them, receive little attention in most histories of the classical foundations of IPE thought. Students are thus presented with an unnecessarily narrow intellectual history, which inhibits mutual understanding among IPE scholars in different parts of the world. This neglect also prevents scholars from recognising earlier 'global conversations', which may interest those involved in current initiatives to globalise the field.

If the perspectives of earlier thinkers in other regions of the world can be identified in a systemic manner, the history of the classical foundations of IPE thought could be rewritten with a more global focus. To date, however, IPE scholars have not taken up this task with the same energy that their international relations counterparts have begun to devote to incorporating 'non-western' perspectives on the histories of thought in that field (e.g. Acharya 2011; Shilliam 2010; Vasilaki 2012; Seth 2011). While Hobson and others have critiqued the eurocentrism of classical thought, IPE scholars have not 


\section{Globalising the classical foundations of IPE}

thought

yet made much of an effort to 'globalise' the content of the canon itself.

This important task requires a book-length study. As a first step, however, this article explores one way in which the history of the classical foundations of IPE thought could begin to be told from a more global perspective. ${ }^{1}$ It examines how thinkers outside Europe and the United States engaged with and contributed to discussions associated with the three classical traditions of economic liberalism, economic nationalism and Marxism. This focus imposes important limits on the range of ideas being analysed, and is adopted here simply because of space constraints. Other approaches to building a more 'global intellectual history' of IPE's classical foundations that are not constrained in this way also need to be pursued actively. ${ }^{2}$

\section{Classical economic Ifberalism}

The emergence of classical economic liberalism is usually closely associated with the publication and influence of Adam Smith's The wealth of nations (1976 [1776]), and its advocacy of freer markets. Smith did not, however, fully develop the international dimensions of classical economic liberalism. Although he called attention to the positive-sum nature of international trade (e.g. Morrison 2012), Smith also strongly defended among the most notorious of his country's trade restrictions at that time, the Navigation Acts, on the grounds that they contributed to the country's naval power (e.g. Earle 1953). It fell instead to 19th-century economic liberals to consolidate the international side of classical economic liberal thought more thoroughly. Particularly important was David Ricardo (1817 [1948]), who developed the core economic case for free trade among countries: the theory of comparative advantage. Thinkers such as Richard Cobden added a more political rationale for free trade that addressed Smith's earlier security concerns, arguing that trade 
liberalisation would generate peace by cultivating interdependence, and undermining the social power of the war-mongering aristocratic classes (Cain 1979).

IPE scholars often note how the core 19th-century liberal belief that free trade among countries generated both prosperity and peace became popular across Europe, encouraging various initiatives to liberalise trade both at home and abroad. But this thinking was also influential beyond Europe in the $19^{\text {th }}$ century in ways that deserve greater recognition by IPE scholars. One such place was the Ottoman Empire, where growing local support for economic liberalism helped to provide some of the justification for the 1838 Anglo-Ottoman Commercial Treaty that liberalised trade with Britain as well as within the Ottoman empire (Özveren 2002: 135). Interestingly, both Ottoman and British leaders hoped the treaty would constrain the ambitions of Muhammad Ali, the governor of Ottoman Egypt, who had actively promoted the growth of local manufacturing in Egypt with import embargos and state monopolies (Al-Sayyid Marsot 1984). Cobden himself had been a strong critic of Ali and his cotton textile factories, arguing during a visit to Cairo in 1836 that Egypt should stick to growing cotton for British industry: 'All this waste is going on with the best raw cotton, which ought to be sold with us' (quoted in Morley 1906: 67). Ali initially refused to abide by the 1838 treaty, but backed down when faced with the threat of British intervention, leaving Egypt's new industries to be undermined by cheap European imports and by foreign merchants who bought up local raw materials at more competitive rates (Al-Sayyid Marsot 1984: 250-2; Özveren 2002: 136). In the following years, the Egyptian economy increasingly centred on the export of cotton and other raw materials, a development encouraged by local elites in Egypt and the Ottoman Empire as a whole who supported economic liberal ideals. Özveren (2002: 137) notes how the 'intellectual hegemony of this liberal perspective lasted right into the 1870s' (see also Özveren 2015). 


\section{Globalising the classical foundations of IPE thought}

Economic liberal ideas also found local supporters in Bengal in the early to mid- $19^{\text {th }}$ century, particularly among Calcutta merchants and land owners who were frustrated by the East India Company's monopoly control of trade. Sartori (2008: 90) describes how, in the 1830s, the dominant merchant Dwarkanath Tagore advocated 'free trade and the abolition of Company monopoly', and 'was sincerely committed to liberal political economy and a vision of cosmopolitan empire in which Indians could participate politically and economically as full subjects of the British Crown, even taking seats in the British Parliament'. Sartori (2008: 22) also notes how some liberal reformers 'struggled polemically against forms of social conservatism in the name (at least in principle) of the emancipation of the rational, self-interested individual from the bondage of custom and discrimination ... this discourse was implicitly grounded in the ideal of free exchange in civil society propounded by classical political economy'.

The liberal critique of mercantilist colonial trade restrictions also resonated in early $19^{\text {th }}$ century Latin America, in those regions still under Spanish or Portuguese colonial rule. It is noteworthy, for example, that Adam Smith's work was first translated into Portuguese in Brazil in 1811-12 rather than in Portugal itself (Cardoso 2014: 138). Similarly, a Mexican official financed the first two editions of the most widely used Spanish-language liberal political economy textbook in much of the $19^{\text {th }}$ century, one that denounced mercantilism and advocated Ricardian economics and free trade. That volume was also disseminated throughout Central America by one of the leaders of Central American independence, José Ceclio del Valle (Almenar 2014).

Economic liberalism continued to garner support in Latin America in the middle decades of the $19^{\text {th }}$ century, particularly among merchant classes and large landholders producing for export who strongly 
endorsed the region's role as an agricultural and raw material exporter to Europe. In an analysis of Colombia from the 1850 s to the 1870 s, Cristina Rojas (2002) shows how these elite groups also had broader reasons for endorsing this international division of labour. Identifying with Europe culturally, they preferred to import European goods and clothing rather than wear textiles produced by local artisans who were mestizos, Indians, blacks and women, and 'were perceived as "barbarians" in need of civilisation before they could be incorporated into the productive world' (Rojas 2002: 105). She also notes how the enthusiasm of local elites for free trade often went hand in hand with their endorsement of the use of coercive labour on haciendas in semi-slave conditions. Their willingness to back economic liberalism internationally while rejecting it domestically in this way was justified once again on the grounds that local labour was not 'civilised'.

The link between civilisational discourse and liberal political economy was also prominent in Europe. Andrew Phillips (2011: 12-13) shows how British Victorian liberalism was associated with 'a hybrid civilising mission - pithily encapsulated in the contemporary slogan "commerce, Christianity and civilisation" that decisively conditioned its engagement with non-European peoples throughout the $19^{\text {th }}$ century'. He continues: 'Within the Asian context, this mission implied for Britain the task of liberating Asia's millions from the threefold scourges of monopoly, tyranny and idolatry via the introduction of the beneficent influences of free trade, "responsible government" and Protestant Christianity.' Phillips details how this British 'civilising mission' justified the use of force to impose free trade on reluctant foreign governments such as China (although Cobden himself criticised the Opium Wars as a barbaric British act; Phillips 2011).

The idea that the promotion of free trade and civilisation went hand in hand also encountered many sceptics outside Europe, even among 


\section{Globalising the classical foundations of IPE thought}

those who displayed some sympathy to European ideas more generally. Watching the activities of European merchants in his region, the British-trained Sierra Leonean doctor James Africanus Horton - who had converted to Christianity, embraced Victorian values, and backed the general British goal of leading Africans into 'civilised Christian life' (Horton 1969 [1868]: 177) - was one such sceptic. In his 1868 analysis of the political economy of British West Africa, Horton (1969 [1868]: 75) argued that the notion that trade would bring civilisation was 'a doctrine that has been disproved in every part of the world where the merchant's sole purpose is to acquire a fortune, and where he is not restrained in his actions by a civilised Government'.

Some economic liberals in Japan also had mixed feelings about free trade. Japan was one of the Asian countries whose markets were liberalised by coercion; in this case, American warships forced the Tokugawa leadership in 1853-4 to abandon their policy - in place since the 1640 s - of tightly controlling external trade. A group of Japanese thinkers who studied in Europe and America in the 1860s quickly endorsed the liberal economic ideas they had learnt abroad, seeing them as universal principles that Japan needed to accept as part of its wider embrace of 'civilisation and enlightenment' (Morris-Suzuki 1989: 49, 53-55; Mizuta 1988). But their support for the dismantling of domestic feudal barriers to commerce was much stronger than their backing of free trade between Japan and other countries. For example, the most prominent Japanese populariser of Adam Smith's ideas, Yukichi Fukuzawa, worried that foreigners might use free trade to leave Japan poor and dependent as a producer of just primary products. In his view, Japanese merchants had a 'public duty' to be 'fighting the war of trade against foreign countries', in which he thought they might need the active support of the Japanese government (quoted in Sugiyama 1988: 49). 


\section{Eric Helleiner}

\section{Classical economic nationalism}

This latter view was in fact widespread among the Japanese officials who came to power after the 1868 Meiji Restoration. They were determined to avoid the fate of China by strengthening their country, particularly by means of industrialisation. Because of the unequal trade treaties imposed by foreign governments, tariffs could not be used to protect local manufacturing firms against external competition. The Meiji leaders turned instead to supporting industrial growth through mechanisms such as subsidies, government contracts, state-owned firms, the acquisition of foreign skills and technology, and the strengthening of national infrastructure. The results were impressive: Japan's industrialisation accelerated rapidly, and its status as a rising international power was soon confirmed by its defeat of China in 1895 and of Russia in 1905.

The Meiji government is often seen to have followed the advice of European and American economic nationalists such as Friedrich List, Alexander Hamilton and Henry Carey. These critics of economic liberalism saw free trade as a weapon used by Britain to subordinate other countries. From their standpoint, free trade locked the rest of the world into agricultural production, while Britain increasingly monopolised manufacturing activities that were key to military success and economic growth. These economic nationalists urged countries to protect and foster local industries in order to cultivate what List called their 'productive powers', just as Britain itself had done earlier in its rise to power. Underlying these arguments was an emphasis on the importance of the nation and what List (1904 [1841]: 97) called 'its prosperity, civilisation and power', as well as a concomitant critique of the cosmopolitanism and materialism of economic liberalism. ${ }^{3}$ 


\section{Globalising the classical foundations of IPE thought}

These arguments built upon the ideas of earlier European thinkers who are sometimes described as 'mercantilists'. The idea that there was a coherent body of thought that should be labelled 'mercantilism' is controversial, but the term is often associated with 17th and 18th-century European thinkers who prioritised the generation of trade surpluses via activist state policies such as export subsidies, restrictions on imported manufactured goods, and preferential shipping rules. Some of these thinkers favoured trade surpluses because of bullionist views that wealth derived from precious metals such as gold and silver. But the core goal of most of those thinkers was to maximise the power of their states within the competitive and conflictual European state system by fostering strategic industries, and accumulating bullion to pay mercenaries and acquire military supplies (Reinert 2011).

It is certainly true that the ideas of European and American economic nationalists were reflected in the writings of key Meiji officials involved in formulating Japanese economic policy, such as Ôkubo Toshimichi and Maeda Masana, both of whom had travelled abroad (e.g. Sagers 2006: 99). But many of the Meiji initiatives went far beyond the proposals outlined by European and American thinkers. Moreover, the ideas of those and other Meiji officials were initially shaped less by List, Hamilton and Carey than by a set of local ideas known as 'kokueki thought' that had emerged in the distinctive political environment of Tokugawa Japan (Roberts 1998: 24; Metzler 2006, Sagers 2006).

During the Tokugawa era, Japan's educated elite was influenced by Confucian thought that had traditionally seen commerce and merchants in a quite negative light. But the promotion of commerce began to be viewed more positively because of growing competition for prestige and wealth among the enormous number of localised political entities that co-existed in Tokugawa Japan, each with its own judicial, taxation, money-issuing and military powers (Sagers 
2006: 137). In the context of this competitive 'small interstate system' (Metzler 2006: 108), some Japanese thinkers began to urge local authorities (the daimyos) to support the "prosperity of the country' - or kokueki - as part of their Confucian obligation to 'order the realm and save the people' (Roberts 1998). Flourishing in the latter half of the Tokugawa period, advocates of this new kokueki thought encouraged daimyos to minimise their territory's 'imports' from the rest of Japan with trade restrictions, and to promote 'exports' to the wider Japanese market by supporting the production of specialised (especially manufactured) goods through policies such as targeted subsidies, monopoly production, and the recruitment of skilled tradespeople. Commerce was increasingly seen as a zero-sum, war-like activity intended to maximise local competitiveness and the accumulation of precious metals.

Many of those involved in Japanese economic policy-making during the early Meiji period came from regions such as Satsuma, where kokueki thought had been very influential. After the Meiji restoration, they simply shifted their focus from the task of maximising the power and wealth of their local region to that of the Japanese nation as a whole. Indeed, some kokueki thinkers had advocated this shift even before the opening of Japan (Sagers 2006: 28-9). It was not until the 1880s that the ideas of western economic nationalists became very influential in Japan; the works of Carey and List were not even translated into Japanese until 1884-5 and 1889 respectively (Mizuta 1988; Metzler 2006: 114-5; Morris-Suzuki 1989: 60-1). As Sagers (2006: 108) puts it in the case of Ôkubo, the ideas of those western thinkers were simply drawn upon 'to validate and refine strategic economic policies that had evolved in Satsuma and other domains'.

While Japanese economic nationalism had these local roots, a number of the Japanese thinkers who developed kokueki thought were involved in 'Dutch learning' through which they had access to 


\section{Globalising the classical foundations of IPE}

thought

foreign writings (via an isolated and tightly controlled Dutch enclave in Nagasaki which the Tokugawa leadership allowed to exist). Some, such as Honda Toshiaki, supported their views with explicit references to European 'mercantilist' writing, while others, such as Takano Chôei, invoked the experience of Holland and England in promoting commerce, noting that 'through trade they became rich and powerful countries' (quoted in Sagers 2006: 66; see also 28-9). But kokueki thought also grew out of, and responded directly to, the distinctive environment of Tokugawa Japan, and its content was not simply derived from European thought.

A similar point can be made about the impetus behind the pro-manufacturing policies put in place by Muhammad Ali in early 19th-century Ottoman Egypt, as discussed previously. Afaf Lutfi Al-Sayyid Marsot (1984: 97) notes that these policies reflected Ali's strong 'mercantilist' world view that trade was a zero-sum game, and that domestic industrialisation was crucial for building and protecting his power. As he once told a French visitor, the factories he was promoting in Egypt 'liberate me today from the tribute which European industry used to levy on Egypt, and the sums with which I paid for your cloth and silks now remain in the country' (quoted in Al-Sayyid Marsot 1984: 178). When defending his policies to British officials (who were often very critical of his economic activism), Ali sometimes suggested that he was simply copying earlier British and French practices (Al-Sayyid Marsot 1984: 172, 174-5). But Al-Sayyid Marsot's detailed analysis gives the impression that Ali's world view was shaped largely by his own pragmatic experiences as a merchant and soldier, and by his drive to accumulate power in the context of various challenges to his rule. ${ }^{4}$ As Al-Sayyid Marsot (1984: 97) puts it in describing the economic beliefs of Ali and his top officials, "it was not that the wali and his men were self-consciously mercantilist, for, after all, the term was probably unknown to them, but they espoused economic policies which faithfully followed mercantilist principles'. 
The same appears to have been true of the 'mercantilist' thinking of the Asante leadership in 19th-century West Africa. Between the late 1830s and early 1880s, Asante authorities tightened their control over all trade in their territory through a body called the Company of State Traders that was headed by the Asante leader. Wilks (1975: 691) describes this as the 'great age of mercantilism', in which a large share of the economic activity in Asante territory 'was derived from the operations of the Company'. After Mensa Bonsu came to power in 1874, initiatives to fend off British power through political and economic reforms intensified, and Wilks (1975: 720) notes that 'mercantilism and neo-mercantilism became the dominant ideologies within the Asante establishment'. Wilks does not discuss devote much analysis to the source of these ideologies, but they appear to have emerged as a pragmatic response to external challenges facing the Asante. In contrast to late 19th-century Japan, however, the influence of those ideas was short-lived. Growing opposition from merchants and the lower classes culminated in a coup in 1883 , followed by political instability, and annexation in 1896 by the British.

In other regions such as Latin America, the influence of European and North American economic nationalist thought was much clearer during the $19^{\text {th }}$ century. For example, Brazilian industrialists and politicians such as Amaro Cavalcanti and Serzedelo Correia invoked the ideas of List and Carey when calling for tariff protection and greater state support for industrialisation in the late 19th and early 20th centuries (Boianovsky 2012: 666-7). In Argentina, supporters of economic liberalism also encountered growing criticism at this time from List-inspired economic nationalists who argued that free trade did not support 'national solidarity' and was 'lacking in the very concept of nationality' (quoted in Bryan 2010: 64). These critics included prominent politicians such as Carlos Pellegrini, who backed greater state support for industrialisation in the form of trade protectionism and government monopolies (Boianovsky 2012). 


\section{Globalising the classical foundations of IPE thought}

Even Pellegrini's central role in crafting Argentina's adoption of the gold standard in 1899 was driven by his economic nationalist thinking. This monetary reform - supported in many other countries by economic liberals - was designed to protect local industry against currency appreciation at the time (Bryan 2010).

Ironically, Latin American references to List's ideas declined in the 1930s just at the time that the region's import-substitution industrialisation (ISI) began to accelerate. Boiasnky (2012) attributes this phenomenon to the fact that protectionists began to cite instead the ideas of the Romanian economist Mihail Manoilescu, who offered a more sophisticated economic analysis of the benefits of tariffs. In Brazil, for example, Manoilescu's 1929 book was quickly translated into Portuguese, and published with the support of leading industrialists (Boainsky 2012). Manoilescu's ideas may also have appealed to some because he combined his detailed economic analysis with a broader political discourse about the struggle between 'proletarian' and 'plutocratic' nations, and the need for a kind of 'socialism among nations' (quoted in Love 1996: 84).

Colonial India is another place where European and American economic nationalist thought began to attract more attention in the last third of the $19^{\text {th }}$ century. By this time, the Calcutta business leaders who had trumpeted economic liberalism in the 1830s and 1840s had lost influence to European commercial interests. The latter had seized the commanding heights of the local economy and were 'overwhelmingly hostile to the participation of native capital and to the employment even of British-trained Indians' (Sartori 2008: 96). Colonial India had become primarily an exporter of primary products and a captive market for British industrial exports that severely undermined local manufacturers, particularly after the 1879 repeal of import duties. This economic transformation encouraged growing Indian nationalist criticism of colonial 
economic policy, and widespread demands for the protection of local industry.

Many of the leading critics were closely linked to the Indian National Congress, and included Dadabhai Naoriji, who developed an innovative analysis of how colonial rule was draining enormous wealth from India to Britain. To support this 'drain theory', Naoriji pointed to many features of the colonial economy ranging from payments for imports of British products to the interest charges on the colonial government's external debt. His critique of colonial rule became well known among European Marxist theorists of imperialism such as Karl Kautsky, with whom he had an extended correspondence (Goswami 2004: 226). Goswami (2004: 11) also notes how it 'anticipated twentieth-century dependency frameworks forged by Latin American intellectuals'.

Another well-known Indian economic nationalist associated with the Congress was Mahadev Govind Ranade. Influenced by List and other foreign economic nationalists, Ranade critiqued economic liberals for failing to recognise the distinctiveness of Indian conditions and the importance of nationalist economic, political and cultural goals (Goswami 2004). He argued that free trade policies imposed by Britain had deindustrialised the Indian economy and transformed it into a '[p]lantation, growing raw produce to be shipped by British Agents in British ships, to be worked into Fabrics by British skill and capital, and to be re-exported to the Dependency by British merchants to their corresponding British firms in India and elsewhere' (quoted in Goswami 2004). Ranade wanted to see tariff protection and government support for Indian industry, but he also recognised that India's colonial status constrained the possibilities for the kind of economic nationalism that List and others advocated: 'It is not open to us to adopt certain plans of operation, which, however much they might be condemned on abstract grounds, have been followed with practical success in many of the most enlightened 


\section{Globalising the classical foundations of IPE thought}

countries of Europe and America' (quoted in Gopalakrishnan 1959: 106)

Given that the colonial government would not protect and support local industry, Indian economic nationalists were forced to innovate. Particularly important in the early $20^{\text {th }}$ century was the emergence of the consumption-based swadeshi movement that urged Indians to boycott foreign goods and purchase only items made by local producers. Goswami (2004: 283, 243) notes that this movement sought to support national economic development 'on the terrain of everyday practices', and 'fused together the abstract and universalistic notion of a common economic collective with a particularised idealist vision of the social body as specifically Hindu'. Regarding the latter, swadeshi thought critiqued the materialism of western civilisation and liberal economic theory on cultural grounds, arguing - in Sartori's words (2008: 156) - that 'the Indian national self recognised that the pursuit of worldly interests, be they political or economic, had meaning only insofar as these ends were subordinated to the higher ends of spirit'.

Provoked by the British partition of Bengal in 1905, the Indian National Congress officially endorsed the swadeshi movement in 1906, and it marked 'the first systematic campaign to incorporate and mobilise the "masses" within the elite structure of institutional or Congress nationalism' (Goswami 2004: 12). Another source of inspiration for the movement at this time was Japan (particularly after its 1905 military victory over Russia), a country that was seen to have succeeded economically while retaining its cultural values (Sartori 2008: 166; Goswami 2004: 54). Local media were initially optimistic that the movement would continue until the people 'have fully developed their own industries and are able to enter the world market on equal terms with other nations' (quoted in Sartori 2008: 162). But it lost momentum within a few years. 
It was revived after World War One by Mohandas Karamchand Gandhi, who put particular emphasis on the support of hand spinning and weaving as well as a broader vision of a decentralised national economy centred on self-governing and relatively self-reliant villages. Gandhi argued that this decentralised economic order would be more democratic and more supportive of spiritual values, as well as less prone to encouraging the kinds of concentrated wealth and power that emerged in large-scale industrial societies (Ghosh 2007). He wanted to 'prevent our villages from catching the infection of industrialism', and argued that 'the Scriptures of the world are far safer and truer treatises on the laws of economics than many of the modern text-books' (quoted in Gopalakrishnan 1959: 190, 188). Gandhi's style of economic nationalism was a far cry from that of List and of the Meiji leaders, as well as that of many members of the Congress Party, including Jawaharlal Nehru, who favoured rapid state-led industrialisation. Interestingly, however, it inspired later 'green' thinkers who emerged in IPE debates as advocates of local self-reliance, and critics of large-scale industrial development (e.g. Helleiner 1996).

There is one further way in which the ideas of economic nationalists such as List were modified and transformed in other contexts. List himself had been very clear that his arguments were meant to apply only to countries in the 'temperate' zones of the earth, and that industrialisation should not be pursued by countries in the 'tropical' or 'torrid' regions (including all of South America). Those regions were, in his view, destined to be commodity exporters partly because of their climate. But his views were also shaped by Eurocentric assumptions about the inferior state of the culture and civilisation of peoples in many of these regions (Boianovsky 2012: 658-62). For example, he argued that 'a regeneration of Asia' was 'only possible by means of an influence of European vital power, by the general introduction of the Christian religion and of European moral laws 


\section{Globalising the classical foundations of IPE thought}

and order, by European immigration, and the introduction of European styles of government' (quoted in Özveren 2002: 141)

Boianovsky (2012: 677) notes that this aspect of List's thought was generally ignored by economic nationalists beyond Europe and the United States. But some, such as Ranade, directly challenged whether there was any justification for separating the world into 'temperate' and 'torrid' zones, and assuming that countries in the latter should never industrialise. He noted that 'the natural fitness of things requires that the manufacturers should spring up where the raw materials grow, and where besides there is demand for the manufactured produce, rather than that bulky goods should be transported many thousands of miles over land and sea, and reconsigned the same way back'. He also called attention to the fact that 'the differences in favour of temperate regions are all modern growths due to the employment of steam machinery and the abundance of cheap iron and coal'. Finally, he reminded his readers that 'the torrid zone people may fairly appeal to past history, when their skilled products found a ready market in temperate kingdoms, and excited such jealousy as to dictate prohibitive sumptuary laws both in ancient Rome and modern England' (quoted in Gopalakrishnan 1959: 121).

\section{Classical Marxist theories of imperialism}

Marxism is the third dominant intellectual tradition usually cited in histories of the classical foundations of IPE thought. Marx himself did not develop a systematic theory of international economic dynamics, but his followers began to do this in the late $19^{\text {th }}$ and early $20^{\text {th }}$ century in an effort to explain the scramble for colonies by the dominant powers at that time. Developed by thinkers such as Rosa Luxemburg, Rudolf Hilferding and Vladimir Lenin, Marxist theories of imperialism suggested that the acquisition of colonies had 
been driven by the dynamics of capitalism: in the face of declining profits, capitalist societies had turned to imperialism to find new markets, new resources and labour to exploit, and new investment locations for surplus capital. But most Marxists saw imperialism as only as a temporary fix for capitalism's problems, given the geographical limits of imperial expansion, the risk of increasingly violent conflict among imperial powers as these limits were reached, and the growing likelihood of social revolution within the imperial powers as economic conditions worsened, and unpopular wars broke out. As Lenin (1916 [1970]: 14) put it, imperialism was thus the 'highest stage of capitalism', as it marked 'the eve of the social revolution of the proletariat'.

Although initially developed by European thinkers, Marxism and Marxist theories of imperialism were globally influential. Histories of IPE thought generally focus on the link between these theories and the rise of dependency theory in Southern countries in the 1960s and 1970s, a development that helped to give rise to the modern post-war field of IPE itself. Dependency theorists reformulated Marxist theories of imperialism from the standpoint of the 'periphery' rather than the 'core'. But Marxist theory affected IPE thought beyond Europe well before the emergence of dependency theory, in ways that deserve more attention.

This influence often did not emerge until after the 1917 Russian revolution. It is important to recognise, as Ilham Khuri-Makdisi (2010) shows so well, how radical ideas relating to political economy were already circulating globally in the late $19^{\text {th }}$ and early $20^{\text {th }}$ centuries through networks fostered by newspapers, periodicals, postal communication, the telegraph, the ease of transportation, migrant communities, and nodal world cities. But her research shows how this emerging 'global radical culture' tended to be associated more with ideas such as social democracy, socialism, Fabianism, anarchism, and anti-colonialism than with Marxism. It was not until 


\section{Globalising the classical foundations of IPE thought}

the Russian revolution that the political salience of Marxist thought suddenly grew in many parts of the world.

This pattern was certainly apparent in Japan, the one non-western country that had emerged as a major new colonial power in the age of imperialism. Marxism did not have strong roots in Japan at the time when that country acquired its first colonies of Taiwan (1895) and Korea (1910). Indeed, the first Japanese translation of Marx's Da kapital did not appear until 1920, and Lenin was relatively unknown in Japan at the time of the 1917 Russian revolution, even among the Japanese socialist movement that had been gaining domestic support (Hoston 1986: 24). During the 1920s, however, Marxist thought rapidly gained influence, and by 1927 it had even 'begun to rival the influence of classical western - primarily British - schools of economics in Japan's leading Tokyo Imperial and Kyoto Imperial universities, the training grounds for Japan's bureaucrats and nongovernmental political leaders' (Hoston 1986: 27-8).

In 1927, a major debate broke out in Japanese Marxist circles about the relevance of Lenin's theory of imperialism to the Japanese case (Hoston 1986: ch 4). The debate was provoked by the Marxist journalist and peasant activist Takahashi Kamekichi, who argued that Japan was engaged in a distinct kind of 'petty bourgeois imperialism' that was not well captured by Lenin's theory. As a late developer with limited resources, Takahashi argued, Japan had engaged in a defensive form of imperialism designed to protect its economic growth and status as an independent state in a world that was increasingly carved up into competing spheres of economic influence. He concluded that Japanese imperialism deserved the support, rather than the criticism, of the left, since it fostered the growth of Japan's proletariat and a socialist revolution. He also suggested that Japanese imperialism could 'liberate' Asia from western powers, arguing that 'just as the interests of the petite bourgeoisie coincide with those of the proletariat and are not one 
with the interests of the grande bourgeoisie, the interests of petty imperialist countries coincide more with those of countries subject to imperialism than with those of large imperialist countries' (quoted in Hoston 1986: 81).

Takahashi's support for Japan's military expansion was controversial on the left (and even more so when he became a consultant to Japanese colonial administrations in the 1930s, and was associated with right-wing nationalist groups after Japan's invasion of China in 1937). Although many elsewhere in Asia had been inspired by Japan's 1905 defeat of Russia, Japanese socialists had opposed the war at the time (Hoston 1986: 21, 74). Takahashi's thesis also appeared around the same time that the Communist International (Comintern) expressed its view that Japanese capitalism still had many feudal characteristics and thus required a 'bourgeois-democratic revolution' before proceeding to a proletarian revolution. That thesis - endorsed by the Japanese Communist Party (which had been founded in 1922) - paved the way for the Comintern's view after Japan's invasion of Manchuria that Japanese imperialism was best explained by enduring feudal elements in Japanese society (Hoston 1986: 72). ${ }^{5}$ Takahashi's explanation of Japanese imperialism was also rejected by those Japanese Marxists who felt the Comintern had underestimated the advanced nature of Japanese capitalism, and who cited their country's imperialism as further evidence to support this view.

European Marxist theories of imperialism were reinterpreted not just by Japanese Marxists but also by Marxists from colonised regions during the 1920s. One of the most important was India's Manabendra Nath Roy. The son of a poor village schoolteacher, Roy had become involved as a teenager and young man in swadeshi politics in the early $20^{\text {th }}$ century (Goswami 2004: 249; Chowduri 2007: 45-6). After leaving India in 1915, he converted to Marxism and ended up in Mexico, where he helped found the Mexican Communist Party in 1919 and (from his exile) the Communist Party 


\section{Globalising the classical foundations of IPE thought}

of India in 1920. Representing Mexico at the 1920 Second World Congress of the Comintern in Moscow, Roy advanced important views about the role of imperialism in colonialised regions, and the political agency of colonised peoples.

Roy argued that imperialist policies over 'Eastern peoples' had prevented them 'from developing, socially and economically, side by side with their fellows in Europe and America'. As he put it, 'skilled craft industries were destroyed to make room for the products of the centralised industries in the imperialist countries; consequently, a majority of the population was driven to the land to produce food grains and raw materials for export to foreign lands' (quoted in d'Encausse and Schram 1969: 161). These arguments echoed earlier Indian economic nationalist thinking, but marked an important intervention in Marxist discussions which had often assumed that imperialism was promoting - rather than restricting the growth of a capitalist economy in the colonies. Marx himself had suggested that he saw colonialism in places such as India - including Britain's destruction of the local textile industry - as a brutal but progressive force that spread capitalism and thus paved the way for socialist revolutions (e.g. Marx 1853 [2013]). From the perspective of Roy, however, colonialism in India had created a severely distorted economy that undermined development. In this respect, his views anticipated the analysis of later dependency thinkers about the link between imperialism and underdevelopment.

Roy also outlined a distinctive position about the agency of the colonised in revolutionary politics. Their political role assumed a much more prominent place on the agenda of the 1920 Comintern meeting than it had at the first Comintern Congress in 1919, where attention had been devoted to encouraging revolution in Europe. As prospects for the latter dimmed, Lenin turned to anti-colonial revolutions as a mechanism to weaken western capitalism and generate economic distress that might encourage a European proletarian uprising. He invited many more delegates from beyond 
Europe to the meeting, and highlighted how the previous Second International (1889-1916) had not been truly international because of the absence of representatives from Asia and Africa (Chowduri 2007: 52). Indeed, the meetings of the Second International had devoted very little attention to the political agency of colonised peoples, or the impact of imperialism on those peoples. The Eurocentrism of the Second International was particularly evident in the early $20^{\text {th }}$ century when some members backed colonialism because of their support for the 'civilising' mission of imperial ideology, and because of the benefits colonialism provided to European workers (d'Encausse and Schram 1969: 15-16; see also Tansel 2015 for the Eurocentrism of classical Marxist thought).

Lenin's draft policy for the 1920 conference suggested that the Comintern should support 'bourgeois-democratic liberation' movements in colonised regions that were challenging imperial rule. Roy strongly endorsed the idea that the success of western revolutionary movements now relied heavily on revolutionary movements in the colonies. Indeed, he even argued that 'the fate of the revolutionary movement in Europe depends entirely on the course of the revolution in the East', a claim that Lenin felt went 'too far' (quoted in d'Encausse and Schram 1969: 151-2). But Roy opposed the idea that the Comintern should support 'bourgeois-democratic liberation' movements because he felt they could not be trusted, particularly in economically advanced colonies where the bourgeoisie was tempted to ally with imperialist interests. In the Indian context and elsewhere, he wanted the Comintern to support local communist parties instead, a stance influenced by his long-standing opposition to the moderate stance of the Indian National Congress as well as his wariness of Gandhi, whose efforts to appeal to local religious and cultural values and preserve local village life struck Roy as more reactionary than revolutionary (Haithcox 1969, Chowduri 2007: 34, 53; d'Encausse and Schram 1969: 151, 162). Lenin agreed to adjust his text, and the Comintern 


\section{Globalising the classical foundations of IPE thought}

backed a resolution to support 'revolutionary-liberation movements in backward countries or among backward nationalities', although Lenin made clear that this wording did not preclude collaboration with bourgeois movements (quoted in d'Encausse and Schram 1969: 152). Roy had taken the lead in challenging Lenin from a non-western perspective, but he had not been alone. The founder of the Communist Party of Persia, Avetis Sultan-Zade, supported Roy's position at the meeting (White 1984). Tan Malaka from Indonesia also subsequently challenged Lenin's condemnation of Pan-Islamism, arguing that the latter was a progressive and anti-imperialist movement rather than a reactionary one (d'Encausse and Schram 1969: 42).

The issues that concerned Roy about the impact of imperialism on the colonised and the agency of non-European peoples also attracted attention in Latin America during the interwar period. For example, the Peruvian activist Raúl Haya de la Torre argued that imperialism had been the first stage of capitalism in Latin America rather than its final stage and that it had contributed to Latin American economic backwardness, and supported feudal structures that blocked future economic progress. After travelling to Russia in the mid-1920s, he also became sceptical of communism and Russian efforts to lead anti-imperialist struggles, efforts which he concluded would primarily serve Russian interests, and showed little understanding of Latin American conditions. Through his Alianza Popular Revolucionaria Americana (APRA), he sought to build a pan-Latin American anti-imperialist movement that was "neither with Washington, nor with Moscow', and drew inspiration from the common heritage of indigenous peoples in the region (quoted in Drinot 2012: 736).

Another Peruvian thinker who invoked this inspiration was one of the best-known Latin American Marxists of this period, José Carlos Mariátegui. After embracing Marxism during travels in Europe 
between 1919 and 1923, Mariátegui worked initially with Haya de la Torre, but then rejected APRA's willingness to work with bourgeois interests, and founded the Partido Socialista Peruano in 1928. While Latin American elites had traditionally looked down upon indigenous peoples, Mariátegui hoped to build a revolutionary movement in which indigenous peoples played a central role and whose end goal was a socialist society underpinned by 'indigenismo' that protected and built upon their traditions and communitarian values. As he put it, 'we have inherited instinctively the idea of socialism ... from the Inca world' (quoted in Subirats 2010: 518). Subirats (2010: 519, 518) notes that Mariátegui's project thus radically opposed the Eurocentric conception of a singular 'civilisation process' by 'defining the Andean socialist revolution as a civilisation process historically rooted in the Incan "communist" economic and social system that later experienced the colonial destruction of the Andean communities, and then evolved towards a modern independent republicanism, and finally would accomplish a socialist order that would restore the Inca-based popular indigenous traditions'.

The question of which kind of anti-imperialist movements outside Europe should be supported by Marxists continued to generate controversy in many regions of the world and within the Comintern, particularly after communists were repressed - often brutally - by nationalist leaders in places such as Turkey and China in the 1920s. The Chinese case was especially problematic because the Comintern had initially forced members of the Chinese Communist Party to join the nationalist Kuomintang (KMT) in the early 1920s as part of Soviet efforts to maintain good relations with the KMT leader Sun Yat-sen (d'Encausse and Schram 1969: 53). Sun himself was sceptical of Marxism, but it is worth noting his important contribution to theories of imperialism since they have usually been neglected by IPE histories of thought. 


\section{Globalising the classical foundations of IPE thought}

At the end of World War One, Sun (1922 [1918]) published a remarkable book entitled The international development of China which called on western governments to create an international organisation devoted to bolstering Chinese living standards through the provision of foreign capital, technology and expertise to state-owned enterprises. Sun argued that this proposed 'International Development Organisation' would benefit not just the Chinese people but also western capitalist powers. Besides providing an outlet for the latter's surplus capital and goods after the war, the intergovernmental nature of this organisation would prevent inter-imperialist war over China.

Sun's ideas not only helped to pioneer modern concepts of international development; they also, in theoretical terms, proposed a way to operationalise a new stage of capitalism involving an alliance - rather than war - among imperialists, a stage that Kautsky (1914 [1970]) had also anticipated in 1914 and given the name 'ultra-imperialism'. While rejected by western powers at the time, Sun's innovative proposal later served as one of the inspirations for the establishment of the World Bank at the 1944 Bretton Woods conference (Helleiner 2014: ch 7). From his non-Marxist perspective, Sun can be credited with pioneering an early blueprint for this institution that many Marxists came to see as a symbol of 'ultra-imperialism' in the post-1945 era.

\section{Conclusion}

Contemporary scholars interested in promoting a 'global conversation' in the field of IPE need to reflect on how the history of the classical foundations of their field is being told. At the moment, these foundations are usually identified with the ideas of European and American thinkers in the $18^{\text {th }}, 19^{\text {th }}$ and early $20^{\text {th }}$ centuries. This approach is problematic not just because those ideas often suffer from Eurocentric biases, but also because it steers attention away 
from the perspectives of historical thinkers in other parts of the world in this period. This article has suggested one way in which the intellectual history of IPE's classical foundations can begin to be 'globalised' by exploring how thinkers located outside Europe and the United States engaged with and contributed to ideas associated with the three well-known IPE traditions of economic liberalism, economic nationalism and Marxism in the pre-1939 era.

This analysis also provides a reminder that 'global conversations' involving thinkers in many regions of the world were extensive in this earlier era. In the $18^{\text {th }}$ century, political economy tracts written by authors from distant lands were being read and translated, even in isolated contexts such as Tokugawa Japan. By the $19^{\text {th }}$ and early $20^{\text {th }}$ century, the transnational flow of ideas became even more widespread in the context of the broader globalisation of goods, people, information and culture.

Many of the 'global conversations' described in this article involved more of a one-way transmission of European and American ideas to the rest of the world. Indeed, those ideas had a much wider global reach than is often identified in histories of the classical foundations of IPE thought. They were usually exported in the context of highly unequal power relations, but, for various reasons, they often held genuine appeal for thinkers in other regions. Economic liberalism attracted those who were critical of colonial trade restrictions (e.g. Bengal, Latin America) as well as elites who sought to justify their role as exporters of resources to Europe and importers of European manufactured products (e.g. Latin America, post-Ali Egypt). Economic nationalism resonated with elites seeking to confront growing European and American economic dominance. Marxist theories of imperialism also offered an attractive analytical framework for those involved in anti-colonial and revolutionary movements. 


\section{Globalising the classical foundations of IPE thought}

When European and American ideas were imported into other regions, they were often modified and transformed in interesting ways. Colombian liberal elites combined their support for free trade at the border with endorsements of coercive labour practices within their country. By contrast, liberals in Meiji Japan embraced domestic liberalisation more enthusiastically than free trade. Pellegrini linked his economic nationalism in Argentina to the project of joining the gold standard. In colonial India, European and American economic nationalist ideas were modified in other ways, including through the consumption-based swadeshi movement, the focus on colonialism's economic impact, the critique of List's analysis of 'torrid zone' countries, and Gandhi's decentralist vision. In the Marxist camp, new categories of imperialism were proposed in Japan, while the impact of imperialism on the colonised and their role in revolutionary politics was reconceptualised by Marxists from India, Persia, Indonesia and Latin America.

The contributions of thinkers outside Europe and the United States went well beyond simply modifying ideas from elsewhere. This article has highlighted how economic nationalists in Meiji Japan drew more heavily on local kokueki thought than the ideas of foreign economic nationalists such as List. Similarly, the 'mercantilist' thinking of leaders such as Muhammad Ali in Egypt and Mensa Bonsu in West Africa appeared to emerge in large part from distinctive local experiences and contexts. Mariátegui also drew on pre-colonial indigenous traditions and values in formulating a new kind of socialist project for Peru that rejected Eurocentric linear conceptions of civilisational progress. The flow of ideas also sometimes went in other directions. For example, Naoriji's drain theory attracted the attention of European theorists of imperialism, and anticipated the ideas of later Latin American dependency theorists. Sun's pioneering proposals after World War One helped shape subsequent European and American thinking about international development institutions. Gandhi's decentralist vision 
informed more recent 'green' advocates of localism in Europe, North America, and elsewhere. These examples may provide important precedents for the kind of 'global conversation' of reciprocal learning that many IPE scholars are calling for today.

As noted at the start, this article does not pretend to provide a comprehensive survey of the perspectives of thinkers in regions outside Europe and the United States, and their contributions to the classical foundations of the field we now call IPE. There are many more examples of relevant historical figures who engaged with classical economic liberalism, economic nationalism and Marxism in interesting and innovative ways before 1939. A wider analysis that focuses not just on these three traditional classical schools would also help to reveal other kinds of perspectives and contributions of thinkers in those regions. This article has tried, however, to take one small step in the direction of globalising the classical foundations of IPE. There is much more work to be done.

\section{Notes}

1. This article is part of a wider book-length study I am writing on this topic.

2. For discussions of 'global intellectual history', see Moyn and Sartori (2013), Gänger and Lewis (2013).

3. The ideas promoted by List, Carey and Hamilton were the most politically prominent version of western 'economic nationalism' in the $19^{\text {th }}$ century, but there were other versions as well; see Helleiner (2002).

4. According to Al-Sayyid Marsot (1984: 32-3, 97, 131-2, 263), Ali was not driven by broader Egyptian nationalist sentiments. He had come to Egypt in 1801 from Ottoman Albania as a mercenary soldier within the Ottoman army and he valued his Ottoman identity very highly while never identifying with Egyptians,. As Al-Sayyid Marsot (1984: 131) puts it, 'To him Egypt was a piece 


\section{Globalising the classical foundations of IPE thought}

of property he had acquired by guile and ability. The Egyptians were there to do his bidding'.

5. Interestingly, this interpretation echoed Joseph Schumpeter's critique of Marxist theories of imperialism.

\section{References}

Acharya, Amitav. 2011. 'Dialogue and discovery: in search of international relations theories beyond the west'. Millennium: Journal of International Studies 39 (3): 619-37.

Al-Sayyid Marsot and Afaf Lutfi. 1984. Egypt in the reign of Muhammad Ali. Cambridge: Cambridge University Press.

Almenar, Salvador. 2014. 'The reception and dissemination of Ricardo's ideas in Spain'. In Gilbert Faccarello and Masashi Izumo (eds), The reception of David Ricardo in continental Europe and Japan. London: Routledge.

Blaney, David and Naeem Inayatullah. 2010. Savage economics. London: Routledge.

Blyth, Mark. 2009. 'Introduction'. In Mark Blyth (ed), Routledge handbook of IPE: IPE as a global conversation. New York: Routledge.

Boianovsky, Mauro. 2012. 'Friedrich List and the economic fate of tropical countries'. History of Political Economy 45 (4): 647-91.

Bryan, Steven. 2010. The gold standard at the turn of the twentieth century. New York. Columbia University Press.

Cain, P. 1979. 'Capitalism, war and internationalism in the thought of Richard Cobden'. British Journal of International Studies 5 (3): 229-47.

Cardoso, José Luis. 2014. 'The diffusion of Ricardo and classical political economy in Portugal'. In Gilbert Faccarello and Masashi Izumo (eds), The reception of David Ricardo in continental Europe and Japan. London: Routledge. 


\section{Eric Helleiner}

Chin, Gregory; Margaret Pearson and Wang Yong (eds). 2014. 'IPE in China: the global conversation'. Review of International Political Economy 20 (6): 1145-1299.

Chowduri, Satyabrata Rai. 2007. Leftism in India, 1917-1947. Basingstoke: Palgrave Macmillan.

Cohen, Benjamin. 2008. International political economy: an intellectual history. Princeton, NJ: Princeton University Press.

2013. Advanced introduction to international political economy. Cheltenham: Edward Elgar.

Cox, Robert. 2011. 'The "British School" in the global context'. In Nicola Phillips and Catherine Weaver (eds), International political economy. London: Routledge.

Drinot, Paulo. 2012. 'Creole anti-communism: labor, the Peruvian Communist Party, and APAR, 1930-1934'. Hispanic American Historical Review 92 (4): 703-36.

Earle, Edward. 1966. 'Adam Smith, Alexander Hamilton, Frederick List: the economic foundations of military power'. In E Earle (ed), The makers of modern strategy. New York: Atheneum.

D'Encausse, Hélène Carrrère and Stuart R Schram. 1969. Marxism and Asia. London: Penguin.

Gänger, Stephanie and Su Lin Lewis. 2013. 'Forum: A world of ideas: new pathways in global intellectual history, c.1880-1930'. Modern Intellectual History 10 (2): 347-51.

Ghosh, B N. 2007. Gandhian political economy. Aldershott: Ashgate.

Gopalakrishnan, P K. 1959. Development of economic ideas in India. New Delhi: People's Publishing House.

Goswami, Manu. 2004. Producing India: from colonial economy to national space. Chicago: University of Chicago Press.

Haithcox, John. 1969. 'Left wing unity and the Indian Nationalist Movement: M N Roy and the Congress Socialist Party'. Modern Asian Studies 3 (1): 17-56.

Helleiner, Eric. 1996. 'International political economy and the Greens'. New Political Economy 1 (1): 59-78. 


\section{Globalising the classical foundations of IPE thought}

. 2002. 'Economic nationalism as a challenge to economic liberalism?'. International Studies Quarterly 46 (3): 307-29.

2009. 'Division and dialogue in Anglo-American IPE: a reluctant Canadian view'. New Political Economy 14 (3): 377-83.

2014. Forgotten foundations of Bretton Woods: international development and the making of the postwar order. Ithaca: Cornell University Press.

Hobson, John M. 2013a. 'Part 1 - Revealing the Eurocentric foundations of IPE: a critical historiography of the discipline from the classical to the modern era'. Review of International Political Economy 20 (5): 1024-54.

Hobson, John M. 2013b. 'Part 2 - Reconstructing the non-Eurocentric foundations of IPE: from Eurocentric "open economy politics" to inter-civilizational political economy'. Review of International Political Economy 20 (5): 1055-1081.

Horton, James Africanus. 1969 [1868]. West African countries and peoples. Edinburgh: Edinburgh University Press.

Hoston, Germaine. 1986. Marxism and the crisis of development in prewar Japan. Princeton: Princeton University Press.

Kautsky, Karl. 1914 [1970]. 'Ultra-imperialism'. New Left Review 59: 41-6.

Khuri-Makdisi, Ilham. 2010. The Eastern Mediterranean and the making of global radicalism, 1860-1914. Berkeley: University of California Press.

Leander, Anna. 2009. 'Why we need multiple stories about the global political economy'. Review of International Political Economy 16 (2): 321-28.

Lenin, Vladimir. 1916 [1970]. Imperialism: the highest stage of capitalism. Moscow: Progress.

List, Friedrich. 1904 [1841]. The national system of political economy. Translated by Sampson Lloyd. London: Longmans, Green and Co.

Love, Joseph. 1996. Crafting the third world. Stanford: Stanford University Press.

Marx, Karl. 2013 [1853]. 'The British Rule in India'. In Darel Paul and Abla Amawi (eds), The theoretical evolution of international political economy. Oxford: Oxford University Press. 


\section{Eric Helleiner}

Metzler, Mark. 2006. 'The cosmopolitanism of national economics: Friedrich List in a Japanese mirror'. In A G Hopkins (ed), Global history. Basingstoke: Palgrave Macmillan.

Mizuta, Hiroshi. 1988. 'Historical introduction'. In Chûhei Sugiyama and Hiroshi Mizuta (eds), Enlightenment and beyond: political economy comes to Japan. Tokyo: University of Tokyo Press.

Morley, John. 1906. The life of Richard Cobden. London: T Fisher Unwin.

Morris-Suzuki, Tessa. 1989. A history of Japanese economic thought. London: Routledge.

Morrison, James. 2012. 'Before hegemony: Adam Smith, American independence, and the origins of the first era of globalisation'. International Organization 66: 395-28.

Moyn, Samuel and Andrew Sartori (eds). 2013. Global intellectual history. New York: Columbia University Press.

Murphy, Craig N. 2009. 'Do the left-out matter?'. New Political Economy 14 (3): 357-65.

Özveren, Eyüp. 2002. 'Ottoman economic thought and economic policy in transition'. In Michalis Psalidopoulos and Marina Mata (eds), Economic thought and policy in less developed Europe. London: Routledge.

Özveren, Eyüp. 2015. 'Turkey and the Turkic linguistic zone'. In Vincent Barnett (ed), Routledge handbook of the history of global economic thought. London: Routledge.

Phillips, Andrew. 2012. 'Saving civilization from Empire: belligerency, pacificism and the two faces of civilization during the second opium war'. European Journal of International Relations 18 (1): 5-27.

Phillips, Nicola. 2009. 'The slow death of pluralism'. Review of International Political Economy 16 (1): 85-94.

Phillips, Nicola (ed). 2005. Globalizing international political economy. Houndmills: Palgrave Macmillan.

Phillips, Nicola and Catherine Waever (eds). 2011. International political economy: debating the past, present and future. London: Routledge.

Reinert, Sophus. 2011. Translating Empire: emulation and the origins of political economy. Cambridge: Harvard University Press. 


\section{Globalising the classical foundations of IPE thought}

Ricardo, David. 1817 [1948]. On the principles of political economy and taxation. London: Dent.

Roberts, Luke. 1998. Mercantilism in a Japanese domain: the merchant origins of economic nationalism in 18th-century Tosa. Cambridge: Cambridge University Press.

Rojas, Cristina. 2002. Civilization and violence: regimes of representation in nineteenth-century Colombia. Minneapolis: University of Minnesota Press.

Sagers, John. 2006. Origins of Japanese wealth and power: reconciling Confucianism and capitalism, 1830-1885. New York: Palgrave MacMillan.

Sartori, Andrew. 2008. Bengal in global concept history. Chicago: University of Chicago Press.

Seth, Sanjay. 2011. 'Postcolonial theory and the critique of international relations'. Millennium 40 (1): 167-83.

Shilliam, Robbie (ed). 2010. International relations and non-western thought: imperialism, colonialism and investigations of global modernity. London: Routledge.

Smith, Adam. 1976 [1776]. An inquiry into the nature and causes of the wealth of nations. New York: Oxford University Press.

Subirats, Eduardo. 2010. 'Mariátegui, Latin American socialism, and Asia'. World Review of Political Economy 1 (3): 517-30.

Sugiyama, Chûhei. 1988. 'Fukuzama Yukichi'. In Chûhei Sugiyama and Hiroshi Mizuta (eds), Enlightenment and beyond: political economy comes to Japan. Tokyo: University of Tokyo Press.

Sun Yat-sen. 1922 [1918]. The international development of China. New York: G P Putnam \& Sons.

Tansel, Cemal Burak. 2015. 'Deafening silence? Marxism, international historical sociology and the spectre of Eurocentrism'. European Journal of International Relations 21 (1): 76-100.

Vasilaki, Rosa. 2012. 'Provincialising IR? Deadlocks and prospects in post-Western IR theory'. Millennium 41 (1): 3-22.

White, Stephen. 1984. 'Soviet Russia and the Asian revolution, 1917-1924'. Review of International Studies 10 (3): 219-32

Wilks, Ivor. 1975. Asante in the nineteenth century. Cambridge: Cambridge University Press. 


\section{Abstract}

\section{Globalising the classical foundations of IPE thought}

Current efforts to teach and research the historical foundations of IPE thought in classical political economy in the $18^{\text {th }}, 19^{\text {th }}$ and early $20^{\text {th }}$ centuries centre largely on European and American thinkers. If a more extensive 'global conversation' is to be fostered in the field today, the perspectives of thinkers in other regions need to be recognised, and brought into the mainstream of its intellectual history. As a first step towards 'globalising' the classical foundations of IPE thought, this article demonstrates some ways in which thinkers located beyond Europe and the United States engaged with and contributed to debates associated with the three well-known classical traditions on which current IPE scholarship often draws: economic liberalism, economic nationalism and Marxism. It also reveals the extensive nature of 'global conversations' about IPE issues in this earlier era.

Keywords: International Political Economy - Intellectual History Globalisation - Economic Liberalism - Economic Nationalism - Marxist Theories of Imperialism 